\section{Platelet Levels of High- and Mega-Dose Methylprednisolone Treatment in Acute Immune Thrombocytopenia}

\author{
Akut İmmün Trombositopenide Yüksek ve \\ Megadoz Metilprednizolon Tedavisi ile \\ Trombosit Seviyeleri
}

To the Editor,

High-dose methylprednisolone (HDMP) therapy was originally used by Ozsoylu et al. in the treatment of immune thrombocytopenic purpura (ITP), and it is also important in the history of Turkish hematology $[1,2]$.

A 16-year-old male (weight: $107.5 \mathrm{~kg}$, height: $167 \mathrm{~cm}$, BMI: $38.5 \mathrm{~kg} / \mathrm{m}^{2}$ ) presented with the complaints of oral submucosal bleeding and purpura. Complete blood count analysis revealed a platelet count of $1900 / \mathrm{mm}^{3}$, and his peripheral blood smear and bone marrow aspiration slides were consistent with ITP. Informed consent was obtained for HDMP and MDMP treatment.

High-dose methylprednisolone was initiated at a dose of $1000 \mathrm{mg} /$ day for 3 days followed by $750 \mathrm{mg} /$ day for 4 days, with each dose administered orally early in the morning. Platelet count reached $28,000 / \mathrm{mm}^{3}$ and $31,000 / \mathrm{mm}^{3}$ on the $3^{\text {rd }}$ and $7^{\text {th }}$ days of treatment, respectively. Mucosal and cutaneous bleeding ceased. Methylprednisolone treatment was continued at a dose of $1 \mathrm{mg} / \mathrm{kg} /$ day for 7 days and tapered over a week. Platelet count was $22,000 / \mathrm{mm}^{3}$ on the last day, but bleeding reoccurred 10 days later and platelet count was $3900 / \mathrm{mm}^{3}$.

Mega-dose methylprednisolone (MDMP) was then given at a dose of $30 \mathrm{mg} / \mathrm{kg}$ ( $3250 \mathrm{mg} /$ day) for 3 days, and then $20 \mathrm{mg} / \mathrm{kg}$ ( $2125 \mathrm{mg} /$ day) for 4 days orally in a single dose in the early morning. Platelet count reached $355,000 / \mathrm{mm}^{3}$, $225,000 / \mathrm{mm}^{3}$, and $381,000 / \mathrm{mm}^{3}$ after 3, 35, and 100 days, respectively (Figure 1). No corticosteroid side effects were observed in this patient [3]. There was no thrombocytopenic attack in the last 12 months.

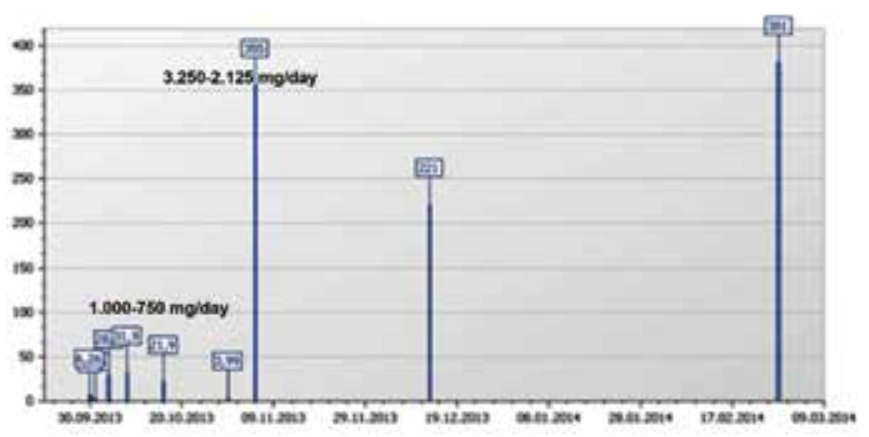

Figure 1. Platelet levels during high- and mega-dose methylprednisolone treatment (platelet count x 103/mm3).
HDMP treatment has been used as a therapeutic choice in childhood acute ITP in Turkey for a long time $[2,4,5]$. The term 'HDMP' was used for this kind of methylprednisolone administration initially, but it was later changed to MDMP since 'HDMP' was also used for $4-10 \mathrm{mg} / \mathrm{kg}$ doses in the literature [6]. It is reported that MDMP treatment differs from conventional corticosteroid ( $2 \mathrm{mg} / \mathrm{kg}$ in divided doses) and pulse methylprednisolone (1000 mg methylprednisolone infusion in $4 \mathrm{~h}$ ) administration, not only by dose (30-100 $\mathrm{mg} / \mathrm{kg}$ initially for 3 days, tapered gradually) but also the time of administration $[7,8]$. The doses $(30 \mathrm{mg} / \mathrm{kg}$ for 3 days and $20 \mathrm{mg} / \mathrm{kg}$ for 4 days) of methylprednisolone for acute ITP treatment were also originally stated by Özsoylu and Ertürk [6].

Acute ITP is usually a benign, self-limited condition that occurs in young children, typically those younger than 10 years. In the majority of these patients, the thrombocytopenia resolves within weeks or a few months of the original manifestation. Glucocorticoid therapy in symptomatic childhood ITP patients has been suggested as an appropriate first-line therapy [2]. Therefore, I think that the results obtained with every high-dose corticosteroid cannot be compared. Based on previous experiences, I wish to conclude that MDMP is a cost-effective treatment for acute ITP, if treatment is required [7].

I would specifically like to emphasize MDMP treatment for these patients, which seems to be the most effective approach in the treatment of this disorder regardless of patient weight. In addition to some reports on intravenous immunoglobulin $[9,10,11]$, MDMP is cheap, safe, and easily applicable in all conditions.

\section{Conflict of Interest Statement}

The author of this paper has no conflicts of interest, including specific financial interests, relationships, and/ or affiliations relevant to the subject matter or materials included.

Key Words: Immune thrombocytopenic purpura, Methylprednisolone, Glucocorticoids, Child, Adolescent

Anahtar Sözcükler: İmmün trombositopenik purpura, Metil prednizolon, Glükokortikoidler, Çocuk, Adölesan

Ali Ayçiçek

Kanuni Sultan Süleyman Research and Education Hospital, Clinic of Pediatric Hematology/Oncology, İstanbul, Turkey

\section{References}

1. Ozsoylu S. Bolus methylprednisolone therapy in chronic idiopathic thrombocytopenic purpura in children. Acta Haematol 1984;72:359-360.

2. Ozsoylu S, Irken G, Karabent A. High-dose intravenous methylprednisolone for acute childhood thrombocytopenic purpura. Eur J Haematol 1989;42:431-435.

3. Özsoylu \$̧. Megadose methylprednisolone (MDMP) treatment. Turk J Hematol 2006;23:120-121. 
4. Özsoylu S, Allahverdi H, Laleli Y, Pirnar A. Platelet survival in childhood idiopathic thrombocytopenic purpura in remission. J Pediatr 1976;89:388-390.

5. Özsoylu \$̧, Karabent A, Irken G, Tuncer M. Antiplatelet antibody in childhood idiopathic thrombocytopenic purpura. Am J Hematol 1991;36:82-85.

6. Özsoylu \$̧, Ertürk G. Oral megadose methylprednisolone for acute childhood idiopathic thrombocytopenic purpura. Blood 1991;77:1856-1857.

7. Özsoylu \$̧. Megadose methylprednisolone for childhood idiopathic thrombocytopenic purpura (ITP). Turk J Med Sci 2005;35:347-356.

8. Engin E, Kılınç Ö, Ozsoylu Ş. Sağlık personelinin serum fizyolojik ile üst solunum yolları enfeksiyonlarından korunması. Yeni Tip Dergisi 1997;14:211-212.

9. Simpson KN, Coughlin CM, Eron J, Bussel JB. Idiopathic thrombocytopenia purpura: treatment patterns and an analysis of cost associated with intravenous immunoglobulin and anti-D therapy. Semin Hematol 1998;35(Suppl 1):5864.

10. Blackhouse G, Xie F, Levine MA, Campbell K, Assasi N, Gaebel K, O'Reilly D, Tarride J, Goeree R. Canadian costutility analysis of intravenous immunoglobulin for acute childhood idiopathic thrombocytopenic purpura. J Popul Ther Clin Pharmacol 2012;19:e166-178.

11. O'Brien SH, Ritchey AK, Smith KJ. A cost-utility analysis of treatment for acute childhood idiopathic thrombocytopenic purpura (ITP). Pediatr Blood Cancer 2007;48:173-180.

Address for Correspondence: Ali AYÇiÇEK, M.D.,

Kanuni Sultan Süleyman Research and Education Hospital, Clinic of Pediatric Hematology/ Oncology, İstanbul, Turkey

E-mail: ayciceka@hotmail.com

Received/Geliş tarihi: November 07, 2014

Accepted/Kabul tarihi: December 02, 2014

DOI: $10.4274 /$ tjh.2014.0436

\section{Gaucher Disease and Gaucher Cells}

\section{Gaucher Hastalı̆̆ ve Gaucher Hücreleri}

\section{To the Editor,}

I read the paper entitled "Gaucher cells or pseudoGaucher cells: that's the question" written by Gören Şahin et al. in a recent issue of this journal. The authors mentioned the main findings of Gaucher cells and pseudo-Gaucher cells in their article without calling attention to the lysosomal enzyme $\beta$-glucocerebrosidase levels [1].

Gaucher disease is inherited as an autosomal recessive disorder resulting from mutations at the glucocerebrosidase locus on chromosome 1q21. In this disorder, glucosylceramide (glucocerebroside) is stored in the reticuloendothelial system due to a deficiency of the lysosomal enzyme $\beta$-glucocerebrosidase [2]. The storage and deposition of

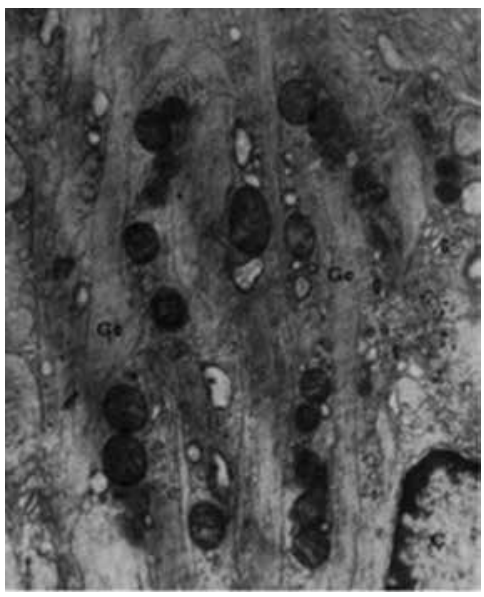

Figure 1. Electron micrograph of a Gaucher cell in the liver. In the cytoplasm, large Gaucher bodies containing tubular elements (25,000 , Gc: Gaucher bodies, Ç: nucleus, G: Golgi apparatus).

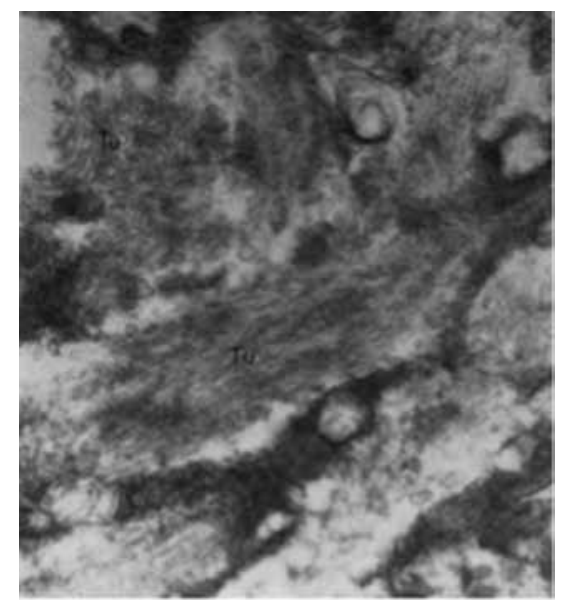

Figure 2. The cytoplasm of a Gaucher cell showed cytoplasmic bodies containing elongated tubular structures $\left(72,000^{\mathrm{x}}, \mathrm{Tu}\right.$ : tubules).

glucocerebroside within these cells, prominently macrophages, results in the appearance of Gaucher cells, which are very large cells with a diameter of 20-80 $\mu \mathrm{m}$, round or polyhedral. Gaucher cells have small, usually eccentrically placed nuclei and cytoplasm with characteristic wrinkles or striations. Electron microscopy reveals that the cytoplasm contains spindle or rod-shaped membrane-bound inclusion bodies of 0.6-4 $\mu \mathrm{m}$ in diameter consisting of numerous small tubules of 13-75 $\mathrm{nm}$ in diameter. Electron microscopy allows the identification of all stages of formation of the inclusions $[3,4]$.

Five patients were diagnosed with Gaucher disease by the presence of many Gaucher cells in the bone marrow associated with organomegaly and cytopenias between 1964 and 1970 in our department at Ankara University. Liver biopsy was performed in one of these patients and electron microscopic study was done. Ultrastructural analysis revealed many Gaucher bodies filled with tubules 